УДК 659.1:330.112.2

\title{
ДОСЛІДЖЕННЯ РЕКЛАМНОГО РИНКУ ПЕРІОДИЧНИХ ВИДАНЬ УКРАЇНИ
}

๑ О. Б. Ткачук, магістрантка, НТУУ «КПІ», Київ, Україна

\author{
В данной статье рассматриваются возможности \\ предоставления периодическими изданиями услуг по \\ размещению в них рекламы как способа получения \\ дополнительной прибыли.
}

This article tells about accordance's of periodicals service possibilities which may contain advertising in order to get additional profits.

\section{Постановка проблеми}

Сучасний український ринок періодики переживає не найкращий час. Можливість читати новини та різні рубрики за допомогою Інтернету зменшила попит на газети та журнали, а з ними прибутки видавничополіграфічних підприємств. Так вийшов у світ останній друкований номер відомого американського тижневика Newsweek. Тепер він видається лише в інтернеті у електронному вигляді. Паперовий Newsweek зазнає збитків з 2007 року. У поточному році його втрати склали близько 22 млн доларів. У той же час відвідуваність сайту видання порівняно $з$ минулим роком зросла на 70 \% [1]. Саме тому, для збільшення прибутковості друкованого періодичного видання, все більше площ віддається під рекламу.

\section{Аналіз попередніх досліджень}

Залучений об'єм реклами в періодичних виданнях є одним 3 актуальних питань протягом останнього десятиліття. Тому що доходу від реалізації продукції недостатньо навіть для покриття витрат. Видавництва знаходяться в постійному пошуку додаткових грошових надходжень. Тому за цією тенденцією постійно слідкують зацікавлені особи, які звертаються за інформацією до експертів та центрів маркетингових досліджень.

\section{Мета роботи}

Метою даного дослідження $€$ аналіз залучення об'єму реклами та зменшення попиту аудиторії, як наслідок зменшення якості змісту періодичних видань.

\section{Результати проведених досліджень}

За даними Міністерства юстиції України, в країні зареєстровано близько тридцяти тисяч друкованих 3МІ, їх концентрація приблизно одне видання на кожні 1,5 тисячі населення. Тим не менш, аудиторія преси планомірно знижується. За даними досліджень компанії TNS Ukraine, загальна аудиторія 
преси в співвідношенні з даними 2001 року, знизилася на 5,1 \%: з 17 млн 14,4 тис. читачів до 15 млн 635,4 тис. Найбільша втрата аудиторії відбулася у щомісячних видань - на 14,3\%: з 12 млн 557,2 тис. до 9 млн 686,2 тис, а у щоденних видань вона знизилася на 9,5 \%: 3 12 млн 518,5 тис. до 10 млн 484,6 тис. Кількість читаючих щотижневі видання порівняно стабільна (різниця в 1,8\% на рівні помилки вибірки): $14 \mathrm{млн}$ 403,1 тис. і 13 млн 690,9 тис [2].

В цей же час обсяг прибутку від реклами збільшується. Згідно з оцінкою експертів, сукупний обсяг реклами в сегменті друкованих ЗМІ в 2010 році склав 2254,2 млн грн., що говорить про зростання на 19,1 \% порівняно з 2009 роком.

Обсяг прямої смугової реклами в 2010 році виріс на 18,5 \% і склав 1444,2 млн грн. Більш ніж 80 \% цієї суми склала реклама у всеукраїнських виданнях (1208,2 млн грн.) - зростання на $18 \%$.

Обсяги прямої смугової реклами в регіональній друкованій пресі в 2010 році склав 236 млн грн, що на 21 \% вище ніж у 2009 році.

У першому півріччі 2011 року реклама в пресі додала 7 \% прибутку.

У пресі збільшення обсягів реклами у сторінках не спостерігалась. Лідерство за рекламними зборами зберігало за собою видавництво «Бурда Україна». Його збори у першому півріччі 2011 році - 129 млн грн за прайсовими цінами. Другу позицію посідав «Український медіахолдинг», третю - «Едіпрес Україна».
Серед друкованих видань перший щабель за рівнем рекламних надходжень залишився за Cosmopolitan. Другу сходинку обіймає Elle, третю - «Коммерсантъ» зі своїми додатками (див. табл. 1) [3].

У січні-березні 2012 року обсяг реклами у загальнонаціональних вітчизняних друкованих $3 \mathrm{MI}$ збільшився на 2 \% у грошовому вимірі. Площа рекламних сторінок при цьому зменшилася на 8 \% - порівняно з першим кварталом 2011 року. Такі дані отримала компанія «Комунікаційний альянс» за результатами свого власного моніторингу.

Жіночі глянцеві журнали Cosmopolitan, Elle та ділова газета «Коммерсанть-Україна» 3 додатком «Коммерсанть. Weekend» склали трійку видань 3 найбільшими рекламними доходами.

До топ-30 видань за рекламним доходом увійшли «Лиза», «Теленеделя», VIVA!, «Отдохни», «Караван историй», «Единственная», Harper's Bazaar, Maxim, «Кореспондент», Marie Claire, «Комсомольская правда в Украине», «Фокус», «Натали», «Автоцентр», «Мой ребенок», Forbes, «Автобазар», «Твой Малыш», Men's Health, «Добрые советы», «АвтоМир», «Аргументы и Факты в Украине».

3 тридцятки вибули «Контракти», «Бизнес», L'Officiel, «Женский журнал», «XXL. Мужской размер", натомість увійшли «Власть денег», «Деловая столица», «Вокруг света» (усі - «Картель»), «Український тиждень» і «Компаньон» [4].

3 вище наведеної статистики видно, що жіночі журнали кори- 
Таблиця 1

Видавництва з найбільшим обсягом доходу від реклами у 2011 році [3]

\begin{tabular}{|c|c|c|c|c|c|}
\hline № & $\begin{array}{c}\text { Найменування } \\
\text { продукції }\end{array}$ & Видавництво & $\begin{array}{c}\text { Бюджет, } \\
\text { млн грн без } \\
\text { ПДВ }\end{array}$ & $\begin{array}{c}\text { Площа } \\
\text { реклами у } \\
\text { вигляді A4 }\end{array}$ & $\begin{array}{c}\text { Площа } \\
\text { реклами у } \\
\text { вигляді } \\
\text { полоси }\end{array}$ \\
\hline 1 & Cosmopolitan & $\begin{array}{l}\text { Sanoma } \\
\text { Magazines }\end{array}$ & 35,7 & 297,8 & 321,6 \\
\hline 2 & Elle & $\begin{array}{l}\text { Hachette } \\
\text { Filipacchi }\end{array}$ & 31,8 & 396,9 & 417,8 \\
\hline 3 & Коммерсанть & $\begin{array}{l}\text { Коммерсанть- } \\
\text { Украина }\end{array}$ & 30,3 & 613,6 & 346,6 \\
\hline 4 & Теленеделя & UMH & 28,2 & 1398,8 & 1164,9 \\
\hline 5 & Лиза & Burda Украина & 23,9 & 300 & 334,8 \\
\hline 6 & Отдохни & Burda Украина & 23,9 & 300 & 334,8 \\
\hline 7 & Единственная & $\begin{array}{l}\text { Эдипресс } \\
\text { Украина }\end{array}$ & 20,1 & 169,2 & 188,1 \\
\hline 8 & VIVA! & $\begin{array}{l}\text { Эдипресс } \\
\text { Украина }\end{array}$ & 18,4 & 220,9 & 202,9 \\
\hline 9 & Корреспондент & $\begin{array}{l}\text { UMH } \\
\text { КП-Друк }\end{array}$ & $\begin{array}{r}7,3 \\
10,5\end{array}$ & $\begin{array}{l}120,3 \\
177,5\end{array}$ & $\begin{array}{l}123,9 \\
182,5 \\
\end{array}$ \\
\hline 10 & Автобазар & Автоцентр & 17,4 & 958,5 & 1163,4 \\
\hline 11 & Натали & Блиц-Информ & 16,4 & 246,7 & 253,7 \\
\hline 12 & Maxim & $\begin{array}{l}\text { Hachette } \\
\text { Filipacchi }\end{array}$ & 15,6 & 197,3 & 209,4 \\
\hline 13 & Женский журнал & Perekhid & 15,6 & 221,1 & 209,5 \\
\hline 14 & Мой ребенок & Burda Украина & 15,3 & 291,4 & 312,2 \\
\hline 15 & Автоцентр & Автоцентр & 13,7 & 340,1 & 318,3 \\
\hline 16 & Marie Claire & $\begin{array}{l}\text { Hachette } \\
\text { Filipacchi }\end{array}$ & 13,4 & 233,8 & 242,3 \\
\hline 17 & Добрые советы & Burda Украина & 13,1 & 203,8 & 220,7 \\
\hline 18 & $\begin{array}{l}\text { Комсомольская } \\
\text { правда }\end{array}$ & $\mathrm{UMH}$ & 13,1 & 331 & 234,1 \\
\hline 19 & Harper's Bazaar & $\begin{array}{l}\text { Sanoma } \\
\text { Magazines }\end{array}$ & 12,5 & 174,5 & 193 \\
\hline 20 & Караван историй & Караван-Медиа & 11,4 & 165,9 & 156,1 \\
\hline 21 & Men's Health & $\begin{array}{l}\text { Sanoma } \\
\text { Magazines }\end{array}$ & 11,1 & 167,1 & 180,4 \\
\hline 22 & Фокус & UMH & 11 & 198,3 & 218,9 \\
\hline 23 & АвтоМир & Burda Украина & 10,9 & 269,5 & 283,2 \\
\hline 24 & Твой Малыш & $\begin{array}{l}\text { Эдипресс } \\
\text { Украина }\end{array}$ & 10,7 & 210,4 & 244 \\
\hline 25 & $\begin{array}{l}\text { XXL. Мужской } \\
\text { размер }\end{array}$ & Вавилон & 10,4 & 161,7 & 160 \\
\hline 26 & Forbes & UMH & 10,3 & 122,6 & 150,8 \\
\hline 27 & L'Officiel & Вавилон & 9,3 & 173,8 & 165 \\
\hline 28 & Полина & $\begin{array}{l}\text { Эдипресс } \\
\text { Украина }\end{array}$ & 8,5 & 130,4 & 143,6 \\
\hline 29 & Деловая столица & Картель & 8,1 & 168,2 & 100,9 \\
\hline 30 & Контракты & $\begin{array}{l}\text { Галицкие } \\
\text { котракты }\end{array}$ & 8 & 162,8 & 160,3 \\
\hline
\end{tabular}


стуються найбільшою популярністю у рекламодавців. Безумовно, великий об'єм реклами $\epsilon$ і в найбільш популярних чоловічих журналах та газетах (спортивні 3МІ, політичні і т. д.), проте кількість комерційних оголошень значно менша.

Це пояснюється тим, що у жінок більше потреб і ці потреби більш дорогі. Також велику роль грає психологічний мотив, який полягає у віднесенні особи до того чи іншого соціального клаcy [5].

Поряд із жіночими глянцевими журналами великі прибутки від реклами мають ділові газети та журнали, такі як Коммерсантъ, Кореспондент, Комсомольская правда в Украине (див. табл. 2).

Кожен новий бюджетний рік преса підвищує розцінки на рекламу. Ринок - це баланс попиту і пропозиції. Відповідно, коли зростає платоспроможний попит, логічним є збільшення ціни пропозиції. Український ринок періодичних видань не є виключенням.

Одним з основних факторів прогнозованого зростання рекламного ринку в сегменті друкованих 3MІ та їі вартості $€$ загальні позитивні очікування щодо пожвавлення українського ринку в цілому.

Оптимістичніше всіх налаштовані ИД «Бурда-Україна» та Український медіахолдинг. «Бурда» вже затвердила і вивісила у себе на сайті нові прайси, згідно з якими реклама в «Автосвіт» подорожчає в середньому на $15 \%$, в «Лізі» - на 17-20\%, в Playboy - на 20-33 \%. УМХ, за словами гене- рального директора Тетяни Єфименко, підвищить розцінки на рекламу на 20-30 \%. Нижня планка підвищення - для давно існуючих видань (таких як «Теленеделя»), верхня - для нових, вартість реклами в яких спочатку занижена порівняно 3 їх потенціалом. Газета «15 хвилин» (KP Media) підвищить вартість реклами в київському випуску на $20 \%$, в регіональних випусках (Донецьк, Одеса, Харків, Львів, Дніпропетровськ) - на 8-9 \%. Холдинг «Медіа інвест груп», за словами директора зі стратегічного маркетингу Наталії Бойко, розглядає можливість підвищення цін приблизно на 30 \% в газеті «Економічні вісті».

Друга група видавництв також передбачає підвищити розцінки, але меншими темпами: ИД «Hachette Filipacchi Shkulev-Україна» - можливо на 10 \%; «Прес-центр» буде міняти ціни диференційовано - на деякі види реклами знизить, на деякі підніме в межах 10-20\%.

«Коммерсант-Україна» прогнозує змінювати ціни не більше ніж на різницю в курсі гривні до долара (з нового року він переходить на гривню). Менеджмент даного журналу вважає, що підвищувати або знижувати розцінки на рекламу нині економічно необгрунтовано, оскільки в обох випадках можна понести збитки. Такі періодичні видання, як «Картель» та «Галицькі контракти» також не передбачають підвищення цін.

\section{Висновки}

Проаналізувавши стан ринку періодики протягом останніх 
Топ-30 видань за доходом від реклами у млн грн без ПДВ

Таблиця 2 у 2012 році [4]

\begin{tabular}{|c|c|c|}
\hline № & Найменування продукції & $\begin{array}{l}\text { Дохід від реклами } \\
\text { у млн грн без ПДВ }\end{array}$ \\
\hline 1 & Cosmopolitan & 16,54 \\
\hline 2 & Elle & 16,43 \\
\hline 3 & Коммерсанть & 15,01 \\
\hline 4 & Лиза & 12,58 \\
\hline 5 & Теленеделя & 11,56 \\
\hline 6 & VIVA! & 11,53 \\
\hline 7 & Отдохни & 10,08 \\
\hline 8 & Караван историй & 10,02 \\
\hline 9 & Единственная & 9,71 \\
\hline 10 & Harper's Bazaar & 8,73 \\
\hline 11 & MAXIM & 7,65 \\
\hline 12 & Корреспондент & 7,17 \\
\hline 13 & Marie Claire & 7,07 \\
\hline 14 & Комсомольская правда в Украине & 6,98 \\
\hline 15 & Фокус & 6,87 \\
\hline 16 & Натали & 6,80 \\
\hline 17 & Автоцентр & 6,69 \\
\hline 18 & Мой ребенок & 6,38 \\
\hline 19 & Власть денег & 6,37 \\
\hline 20 & Forbes & 6,33 \\
\hline 21 & Автобазар & 6,22 \\
\hline 22 & Твой Малыш & 5,90 \\
\hline 23 & Men's Health & 5,75 \\
\hline 24 & Добрые советы & 5,51 \\
\hline 25 & АвтоМир & 5,18 \\
\hline 26 & Деловая столица & 5,02 \\
\hline 27 & Український тиждень & 4,94 \\
\hline 28 & Вокруг света & 4,86 \\
\hline 29 & Комп\&ньОН & 4,74 \\
\hline 30 & Аргументы и факты в Украине & 4,49 \\
\hline
\end{tabular}

років та дії керівництва видавництв стає зрозуміло, що такий метод, як підвищення розцінки на рекламу або збільшення її обсягу поки що $є$ ефективним інструментом отримання додаткових прибутків. Так на прикладі збільшення прибутку таких видань, як Cosmopolitan, Elle та ділова газета «КоммерсантъУкраїна», які успішно застосовують даний метод протягом декількох років, це чітко прослідковується. Проте у майбутньому для видавництв така політика не є перспективною. В умовах інтенсивного використання Інтернету, рекламодавці активно розміщують свою рекламу на інтернет-сайтах. Тому видавництвам необхідно створювати інтернет видання, які принесуть додаткові кошти від розташованої реклами та збільшать свою цільову аудиторію. 
1. Фил Ваба, перевел Колодяжний A. Newsweek перестанет выходить в печатной версии [Электронный ресурс] / Фил Ваба, перевел Колодяжний А. - Режим доступа : http://ru.reuters.com/article/oddlyEnoughNews/ idRUMSE89H03520121018. - Загл. с экрана. 2. Присяжна Л. Роздержавлення державних друкованих ЗМІ : події, факти, коментарі [Електронний ресурс] / Присяжна Л. - Режим доступу : http://www.telekritika.ua/daidzhest/2008-01-08/35852. - Загл. з екрану. 3. Дані компаній «Комунікаційний альянс»/Doors Бюджети вирахувані для комерційної реклами за власною оцінкою «Комунікаційного альянсу»/Doors. 4. Данні TNS Ukraine. Дослідження рейтингів ділових газет і журналів України. 5. Грінченко Г. Д. Маркетинг / Г. Д. Грінченко, О.В.Дубовик : Навчальний посібник. - Київ : Центр навчальної літератури, 2007. - 255 с.

1. Fil Vaba, perevel Kolodjazhnij A. Newsweek perestanet vyhodit' v pechatnoj versii [Jelektronnyj resurs] / Fil Vaba, perevel Kolodjazhnij A. - Rezhim dostupa : http://ru.reuters.com/article/oddlyEnoughNews/idRUMSE89H03520121018. Zagl. s jekrana. 2. Prysiazhna L. Rozderzhavlennia derzhavnykh drukovanykh ZMI : podii, fakty, komentari [Elektronnyi resurs] / Prysiazhna L. - Rezhym dostupu : http://www.telekritika.ua/daidzhest/2008-01-08/35852. - Zahl. z ekranu. 3. Dani kompanii «Komunikatsiinyi alians»/Doors Biudzhety vyrakhuvani dlia komertsiinoi reklamy za vlasnoiu otsinkoiu «Komunikatsiinoho aliansu»/Doors. 4. Danni TNS Ukraine. Doslidzhennia reitynhiv dilovykh hazet $\mathrm{i}$ zhurnaliv Ukrainy. 5. Hrinchenko H. D. Marketynh / H. D. Hrinchenko, O. V. Dubovyk : Navchalnyi posibnyk. - Kyiv : Tsentr navchalnoi literatury, 2007. $-255 \mathrm{~s}$. 